\title{
Expression of Concern to: Therapeutic potential of human embryonic stem cell transplantation in patients with cerebral palsy
}

\author{
Geeta Shroff ${ }^{*}$, Anupama Gupta ${ }^{2}$ and Jitender Kumar Barthakur ${ }^{3}$
}

\section{Expression of Concern: J Transl Med (2014) 12:318 DOI 10.1186/s12967-014-0318-7}

The Editor-in-Chief of the Journal of Translational Medicine is issuing an editorial expression of concern to alert readers that concerns have been raised regarding the ethics of this study [1] and the potential association of the risk of teratoma formation with the transplantation of embryonic stem cells. Appropriate editorial action will be taken once this has been fully investigated. The authors disagree with this notice.

\section{Author details}

${ }^{1}$ Nutech Mediworld, H-8, Green Park Extension, New Delhi 110016, India.

${ }^{2}$ Max Hospital, Saket, New Delhi, India. ${ }^{3}$ Ministry of Home Affairs, Government of India, New Delhi, India.

The online version of the original article can be found under doi:10.1186/s12967-014-0318-7.

\section{Publisher's Note}

Springer Nature remains neutral with regard to jurisdictional claims in published maps and institutional affiliations.

Received: 31 August 2017 Accepted: 31 August 2017

Published online: 18 September 2017

\section{Reference}

1. Shroff G, Gupta A, Barthakur JK. Therapeutic potential of human embryonic stem cell transplantation in patients with cerebral palsy. J Transl Med. 2014;12:318. doi:10.1186/s12967-014-0318-7.

*Correspondence: geetashroff@hotmail.com

1 Nutech Mediworld, H-8, Green Park Extension, New Delhi 110016, India

Full list of author information is available at the end of the article 